\title{
SEMA4D wt Allele
}

National Cancer Institute

\section{Source}

National Cancer Institute. SEMA4D wt Allele. NCI Thesaurus. Code C106609.

Human SEMA4D wild-type allele is located in the vicinity of 9q22.2 and is approximately $137 \mathrm{~kb}$ in length. This allele, which encodes semaphorin-4D protein, plays a role in both axonal growth cone guidance and cell-cell signaling. 